\title{
Article \\ Caloric Restriction and Hypothalamic Leptin Gene Therapy Have Differential Effects on Energy Partitioning in Adult Female Rats
}

\author{
Russell T. Turner ${ }^{1}$, Carmen P. Wong ${ }^{1}$, Kristina M. Fosse ${ }^{1}$, Adam J. Branscum ${ }^{2}$ and Urszula T. Iwaniec ${ }^{1, *}$ \\ 1 Skeletal Biology Laboratory, School of Biological and Population Health Sciences, Oregon State University, \\ Corvallis, OR 97331, USA; russell.turner@oregonstate.edu (R.T.T.); carmen.wong@oregonstate.edu (C.P.W.); \\ fossek@oregonstate.edu (K.M.F.) \\ 2 Biostatistics Program, School of Biological and Population Health Sciences, Oregon State University, \\ Corvallis, OR 97331, USA; adam.branscum@oregonstate.edu \\ * Correspondence: urszula.iwaniec@oregonstate.edu
}

Citation: Turner, R.T.; Wong, C.P.; Fosse, K.M.; Branscum, A.J.; Iwaniec, U.T. Caloric Restriction and Hypothalamic Leptin Gene Therapy Have Differential Effects on Energy Partitioning in Adult Female Rats. Int J. Mol. Sci. 2021, 22, 6789. https:// doi.org/10.3390/ijms22136789

Academic Editor: Oreste Gualillo

Received: 28 March 2021

Accepted: 18 June 2021

Published: 24 June 2021

Publisher's Note: MDPI stays neutral with regard to jurisdictional claims in published maps and institutional affiliations.

Copyright: (c) 2021 by the authors. Licensee MDPI, Basel, Switzerland. This article is an open access article distributed under the terms and conditions of the Creative Commons Attribution (CC BY) license (https:// creativecommons.org/licenses/by/ $4.0 /)$.

\begin{abstract}
Dieting is a common but often ineffective long-term strategy for preventing weight gain. Similar to humans, adult rats exhibit progressive weight gain. The adipokine leptin regulates appetite and energy expenditure but hyperleptinemia is associated with leptin resistance. Here, we compared the effects of increasing leptin levels in the hypothalamus using gene therapy with conventional caloric restriction on weight gain, food consumption, serum leptin and adiponectin levels, white adipose tissue, marrow adipose tissue, and bone in nine-month-old female Sprague-Dawley rats. Rats $(n=16)$ were implanted with a cannula in the 3 rd ventricle of the hypothalamus and injected with a recombinant adeno-associated virus, encoding the rat gene for leptin (rAAV-Lep), and maintained on standard rat chow for 18 weeks. A second group $(n=15)$ was calorically-restricted to match the weight of the rAAV-Lep group. Both approaches prevented weight gain, and no differences in bone were detected. However, calorically-restricted rats consumed $15 \%$ less food and had lower brown adipose tissue Ucp-1 mRNA expression than rAAV-Lep rats. Additionally, calorically-restricted rats had higher abdominal white adipose tissue mass, higher serum leptin and adiponectin levels, and higher marrow adiposity. Caloric restriction and hypothalamic leptin gene therapy, while equally effective in preventing weight gain, differ in their effects on energy intake, energy expenditure, adipokine levels, and body composition.
\end{abstract}

Keywords: obesity; marrow adipose tissue; white adipose tissue; Ucp-1; leptin; adiponectin; bone architecture

\section{Introduction}

Normal weight gain during middle age $(0.25-0.50 \mathrm{~kg} /$ year $)$ is associated with increased risk for several chronic diseases, most notably type II diabetes [1,2]. Hypertension, cardiovascular disease and certain cancers are also positively associated with weight gain [3]. The underlying mechanisms leading to the energy imbalance responsible for normal weight gain in adults are not well understood, but incremental development of leptin resistance, associated with higher circulating leptin, is thought to be a contributing factor [4]. In support, decreases in serum leptin levels in overweight individuals result in improved leptin sensitivity [5]. Whatever the precise mechanism(s) of action, caloric restriction, sufficient to result in a negative energy balance, is a common strategy to lose excess weight and/or mitigate health risks associated with weight gain.

The increase in population level body mass index noted in recent decades is also paralleled by increased prevalence of dieting as a form of voluntary caloric restriction. Prevalence of dieting varies with age, sex, economic status, and ethnicity, but in a recent study, 57-63\% of middle-aged women (35-65 years old) dieted to control weight [6-9]. Weight loss due to caloric restriction may attenuate or reverse some of the health risks 
associated with excessive weight gain, especially in younger individuals. However, the long-term efficacy of conventional weight loss interventions is generally poor, and many individuals weight-cycle through repetitive bouts of weight loss followed by rapid weight regain [10-12]. In addition to likely beneficial effects, caloric restriction has the potential for detrimental side effects. For example, weight loss in adults is often associated with bone loss and, as a consequence, increased risk for osteoporosis [13]. In adult male rats, weight loss induced by caloric restriction resulted in bone loss due to a combination of increased bone resorption and decreased bone formation [14]. In some populations, intentional weight loss is associated with increased mortality [15-17]. Thus, preventing weight gain by maintaining a neutral energy balance during adulthood should be a primary strategy for long duration weight control.

Although a pleotropic hormone with peripheral and central activity, leptin's actions as a regulator of energy balance are primarily centrally mediated $[18,19]$. Importantly, increasing hypothalamic leptin levels bypasses leptin resistance at the blood brain barrier and, compared to ad lib-fed or pair-fed controls, reduces weight gain, and lowers peripheral leptin levels in rodents consuming normal and high fat diets [20-23]. We previously evaluated the long-duration effects of increasing hypothalamic leptin levels using gene therapy (rats injected in 3rd ventricle of their hypothalamus with recombinant adenoassociated virus (rAAV) encoding the rat gene for leptin) on energy balance and bone metabolism in 9-month-old female rats [24]. At study termination, rAAV-Lep treated rats weighed less, had less abdominal white adipose tissue (WAT), and had lower serum leptin compared to rats administered the control vector rAAV-GFP (green florescent protein). These findings suggest that interventions targeted toward increasing leptin sensitivity have the potential to overcome leptin resistance and, thereby, prevent undesirable weight gain. Leptin resistance can be reduced by lowering serum leptin levels [5] or by directly increasing hypothalamic leptin levels using gene therapy [20]. However, it is not clear whether these two approaches illicit similar adaptive responses.

The primary objective of the present study was to compare (1) the effects of increasing hypothalamic leptin gene expression with gene therapy to (2) conventional caloric restriction on weight gain, food consumption, serum leptin and adiponectin levels, abdominal adiposity, marrow adiposity, $U_{c p}-1$ gene expression (as an index of non-shivering thermogenesis) in brown adipose tissue (BAT) and bone. The 18-week study was performed in 9-month-old female rats fed a normal diet to model prevention of age-related weight gain common in healthy adults. The results show that hypothalamic leptin gene therapy and caloric restriction, while both effective in preventing weight gain, differ in their effects on energy partitioning.

\section{Results}

\subsection{Effects of Hypothalamic $r A A V$-Lep or Caloric Restriction on Body Weight and Food Consumption}

The effects of hypothalamic rAAV-Lep gene therapy and weight matching using caloric restriction on body weight as a function of time, net body weight change during the 18 weeks of treatment, food intake/day as a function of time, and average daily food intake are shown in Figure 1. As intended, body weight did not differ with time between the rAAV-Lep and calorically-restricted weight-matched rats (Figure 1A). Weight in the rAAV-Lep rats did not differ from baseline weight at any time point during the 18-week duration of study. Final body weight did not change significantly compared to baseline values $(286 \pm 3 \mathrm{~g}$ ) for either group of rats (Figure 1B). These findings indicate that rAAVLep stabilized body weight in adult rats without reducing food intake. In contrast, the weight-matched rats consumed less food (Figure 1C); average daily food consumption was $15 \%$ lower in weight-matched rats compared to rAAV-Lep rats (Figure 1D). 


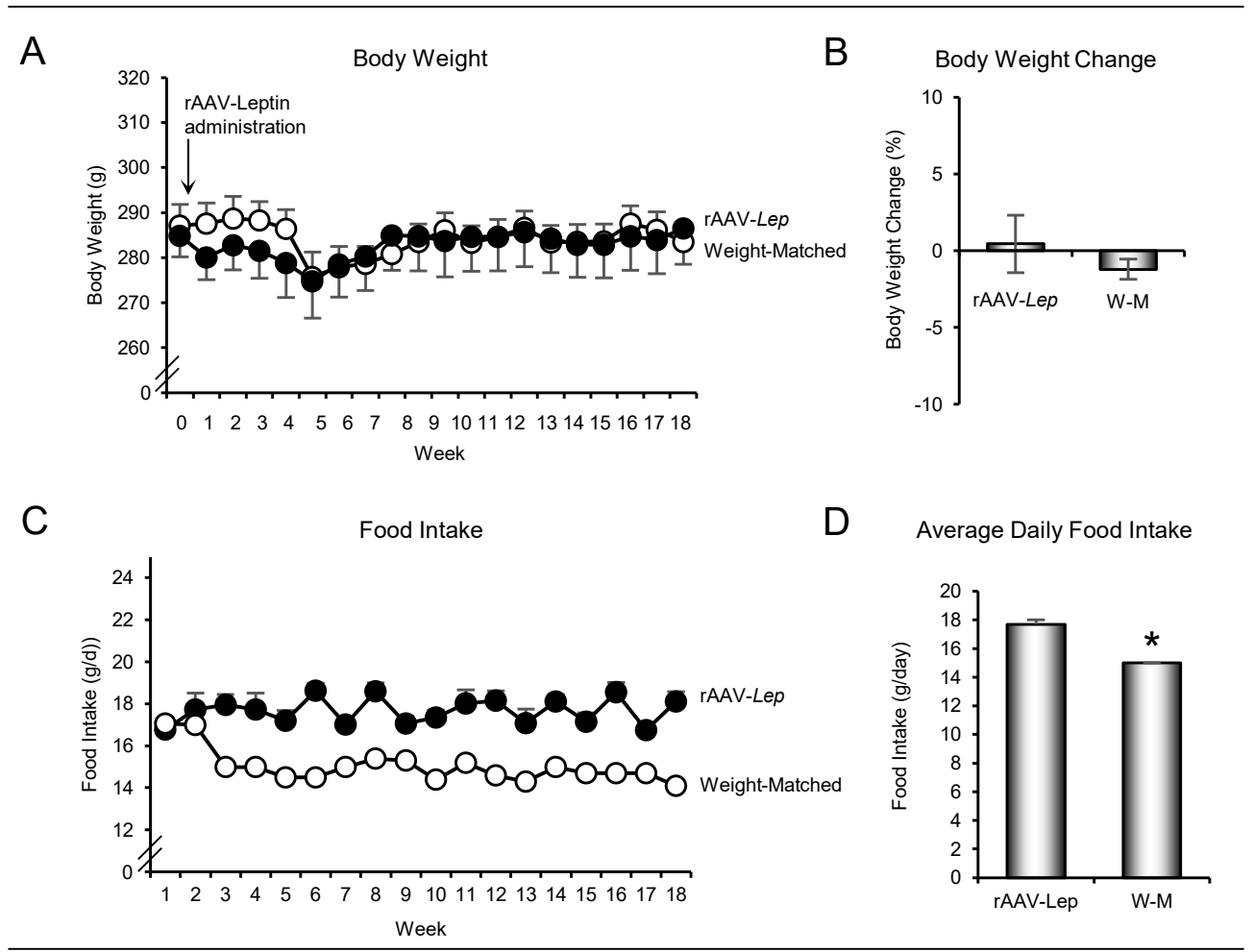

Figure 1. Effects of hypothalamic leptin gene therapy (rAAV-Lep) and caloric restriction (mean 15\% restriction to weightmatch rAAV-Lep treated animals; weight-matched, W-M) on (A) body weight as a function of time, (B) body weight change between initiation and termination of treatment, $(\mathbf{C})$ food intake/day as a function of time, and (D) average daily food intake. Data are mean $\pm \mathrm{SE} ; n=15-16$ /group. ${ }^{*}$ Different from rAAV-Lep,$p \leq 0.05$

\subsection{Effects of Hypothalamic $r A A V$-Lep or Caloric Restriction on Abdominal WAT, Serum Adipokines and Tissue Gene Expression}

The effects of rAAV-Lep treatment and weight-matching on abdominal WAT mass, serum leptin levels, serum adiponectin levels, serum glucose levels, and steady-state mRNA levels for leptin (Lep) in hypothalamus and in abdominal WAT, Ucp-1 (Ucp-1) in BAT, and adiponectin (Adipoq) in WAT are shown in Figure 2. Calorically-restricted weight-matched rats had higher WAT mass (Figure 2A), higher serum leptin (Figure 2B), and higher serum adiponectin (Figure 2C). Serum glucose levels did not differ between treatment groups (Figure 2D). As expected, mRNA levels for leptin in hypothalamus were lower (below limit of reliable detection) in weight-matched rats compared to rAAV-Lep rats (Figure 2E). mRNA levels for leptin in abdominal WAT tended $(p=0.105)$ to be higher in weight-matched rats (Figure 2F). mRNA levels for Ucp-1 in BAT were lower in weightmatched rats (Figure 2G). Significant differences between the two groups were not detected in mRNA levels for adiponectin in WAT (Figure 2H). These findings indicate that, although weight matching using caloric restriction and rAAV-Lep treatment are equally effective in stabilizing body weight in adult female rats, the metabolic response to the two treatments differs. Specifically, weight matched animals required less food to achieve weight stability than rAAV-Lep treated rats. 
A

White Adipose Tissue Mass

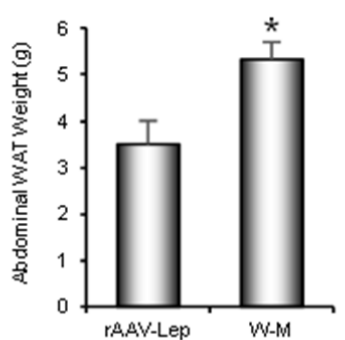

E

Lep Gene Expression in Hypothalamus

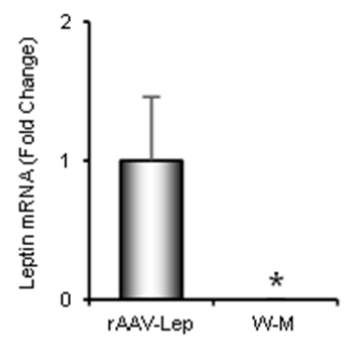

B

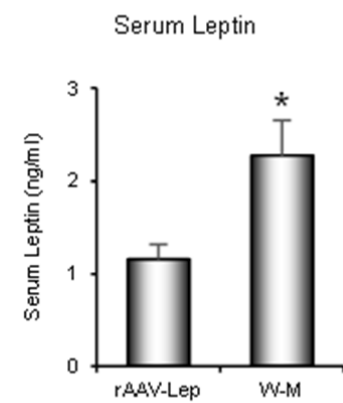

F

Lep Gene Expression in White Adipose Tissue

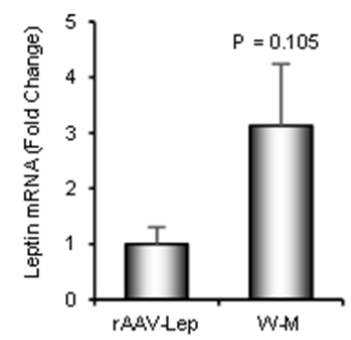

C

Serum Adipone ctin

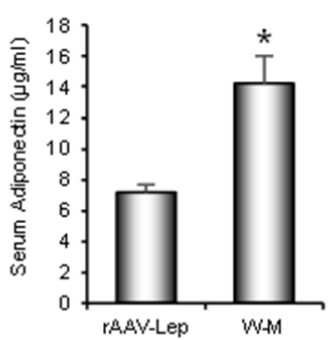

G

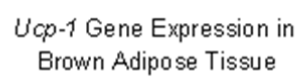

$\mathrm{H}$

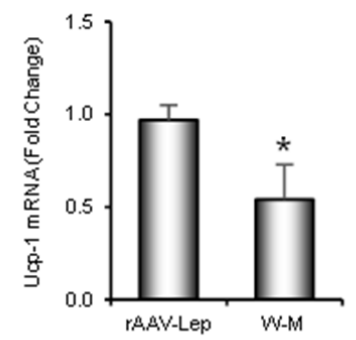

Serum Glucose

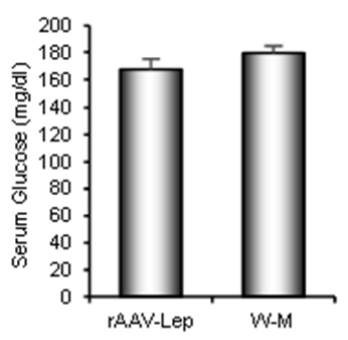

Adjpog Gene Expression in White Adipose Tissue

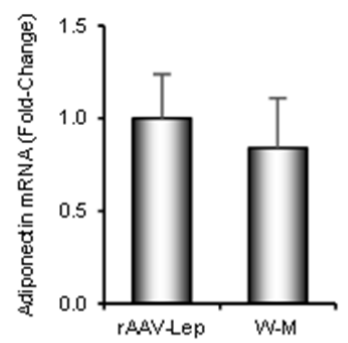

Figure 2. Effects of hypothalamic leptin gene therapy (rAAV-Lep) and caloric restriction (mean 15\% restriction to weightmatch rAAV-Lep treated animals; weight-matched, W-M) on (A) abdominal white adipose tissue (WAT) mass, (B) serum leptin, (C) serum adiponectin, (D) serum glucose, (E) Lep gene expression in hypothalamus, (F) Lep gene expression in abdominal WAT, (G) Ucp-1 gene expression in brown adipose tissue (BAT), and (H) Adipoq gene expression in WAT. Data are mean $\pm \mathrm{SE} ; n=15-16 /$ group for WAT, 14-15/group for leptin, 11-12/group for adiponectin and glucose, 5-12/group for hypothalamic Lep expression, 5-7/group for WAT Lep expression, 5-11/group for BAT Ucp-1 expression, and 7/group for WAT Adipoq expression. * Different from rAAV-Lep, $p \leq 0.05$.

\subsection{Effects of Hypothalamic $r A A V$-Lep or Caloric Restriction on Bone Marrow Adiposity}

The effects of rAAV-Lep treatment and weight-matching on bone marrow adipose tissue (bMAT), in proximal tibia metaphysis, are shown in Figure 3. Adipocyte area/tissue area (Figure 3A), adipocyte number (Figure 3B), and adipocyte size (Figure 3C) were higher in weight-matched rats. Representative images depicting differences in marrow adiposity in the two treatment groups are shown in Figure 3D,E. These findings indicate that, compared to weight matching using caloric restriction, rAAV-Lep treatment results in lower bone marrow adiposity.

\subsection{Effects of Hypothalamic rAAV-Lep or Caloric Restriction on Bone Mass, Architecture, and Serum Markers of Bone Turnover}

The effects of rAAV-Lep treatment and weight-matching on total femur bone area, bone mineral content, and bone mineral density, measured by dual energy $\mathrm{x}$-ray absorptiometry (DXA), and on bone microarchitecture in femur diaphysis, metaphysis and epiphysis measured by microcomputed tomography $(\mu \mathrm{CT})$ are shown in Table 1. Significant differences between rAAV-Lep and calorically-restricted weight-matched rats were not detected for any of the endpoints measured. 


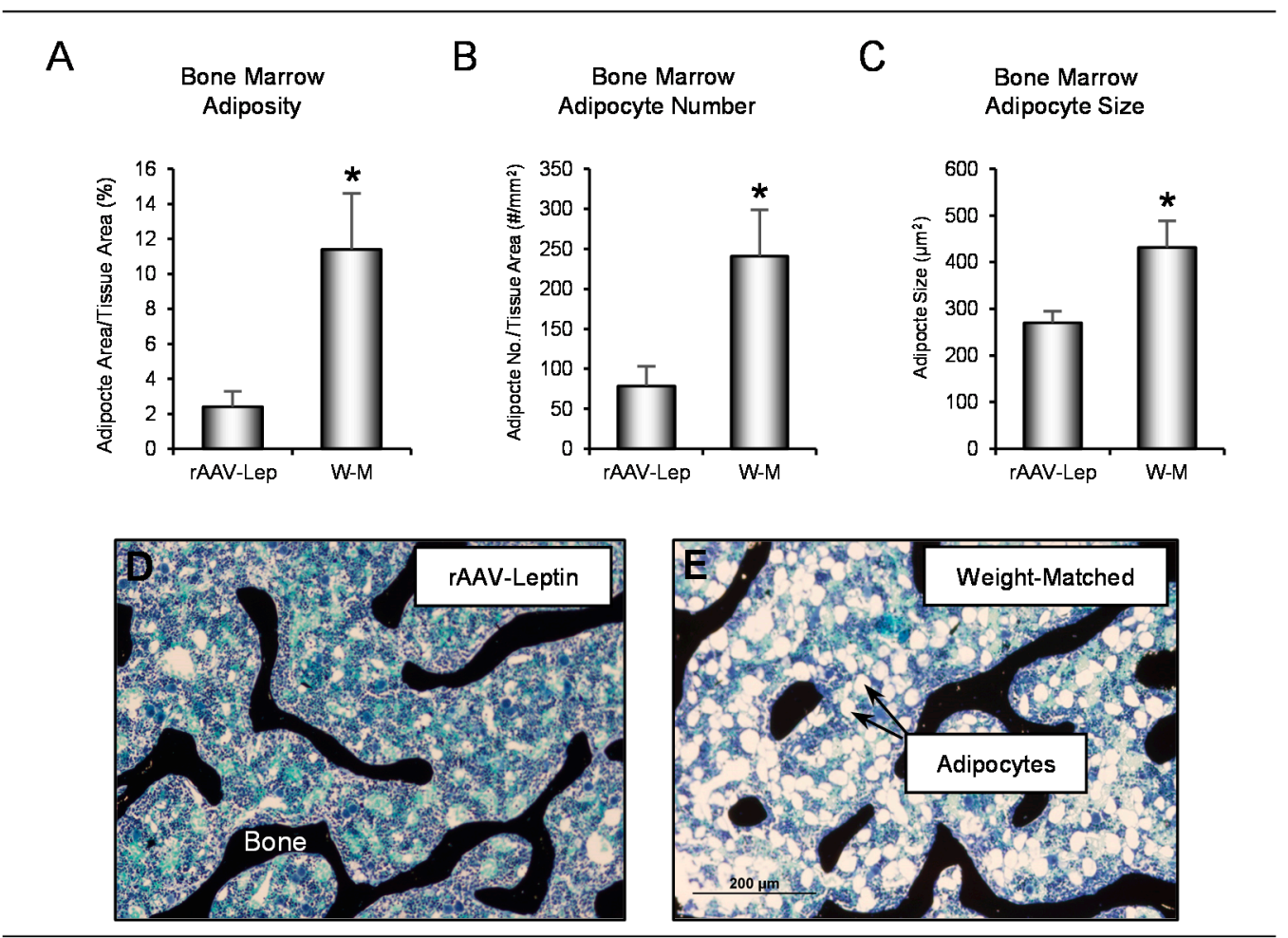

Figure 3. Effects of hypothalamic leptin gene therapy (rAAV-Lep) and caloric restriction (mean 15\% restriction to weightmatch rAAV-Lep treated animals; weight-matched, W-M) on (A) bone marrow adiposity, (B) adipocyte number, and (C) adipocyte size in proximal tibia. Representative images from an rAAV-Lep treated and a weight matched rat are shown in $(\mathrm{D}, \mathrm{E})$, respectively. Data are mean $\pm \mathrm{SE} ; n=5-8$ /group. ${ }^{*}$ Different from rAAV-Lep, $p \leq 0.05$.

The effects of rAAV-Lep treatment and weight-matching on serum CTX, a marker of global bone resorption, and serum osteocalcin, a marker of global bone formation, are shown in Figure 4. Significant differences between rAAV-Lep and calorically-restricted weight-matched rats were not detected for either of the endpoints measured.

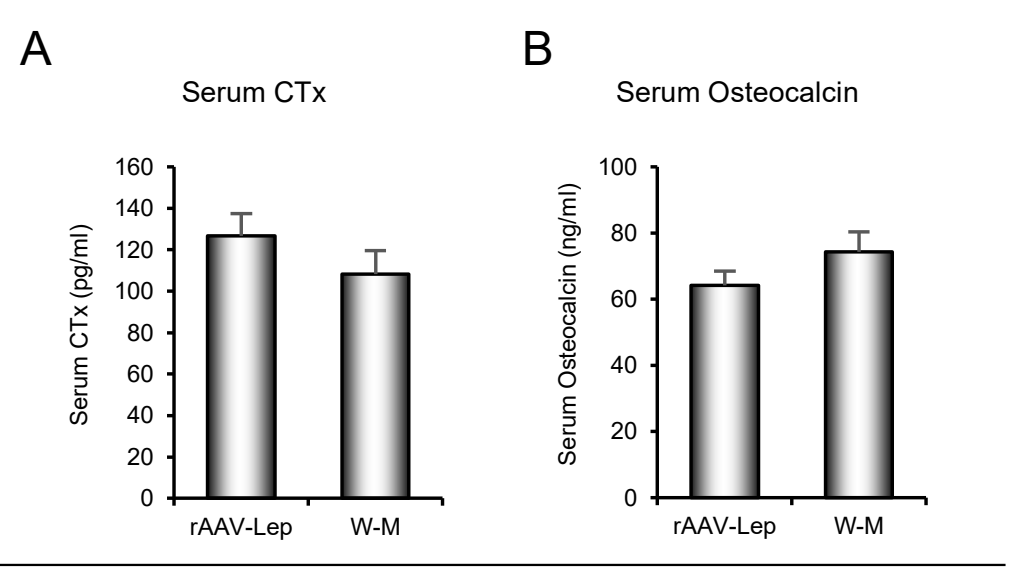

Figure 4. Effects of hypothalamic leptin gene therapy (rAAV-Lep) and caloric restriction (mean 15\% restriction to weight-match rAAV-Lep treated animals; weight-matched, W-M) on (A) serum CTX, a marker of global bone resorption and (B) serum osteocalcin, a marker of global bone formation. Data are mean $\pm \mathrm{SE} ; n=9-11$ /group. 
Table 1. Effects of hypothalamic leptin gene therapy (rAAV-Lep) and caloric restriction (mean 15\% restriction to weightmatch rAAV-Lep treated animals) on bone area, bone mineral content and bone mineral density in total femur and on cortical bone architecture in the femur diaphysis and cancellous bone architecture in the distal femur metaphysis and epiphysis.

\section{rAAV-Lep}

Dual Energy X-ray Absorptiometry

\author{
Total Femur \\ Bone area $\left(\mathrm{cm}^{2}\right)$ \\ Bone mineral content $(\mathrm{g})$ \\ Bone mineral density $\left(\mathrm{g} / \mathrm{cm}^{2}\right)$ \\ Microcomputed Tomography \\ Midshaft Femur (cortical bone) \\ Cross-sectional volume $\left(\mathrm{mm}^{3}\right)$ \\ Cortical volume $\left(\mathrm{mm}^{3}\right)$ \\ Marrow volume $\left(\mathrm{mm}^{3}\right)$ \\ Cortical thickness $(\mu \mathrm{m})$ \\ Polar moment of inertia $\left(\mathrm{mm}^{4}\right)$
}

Distal Femur Metaphysis (cancellous bone)

Bone volume/tissue volume (\%)

Connectivity density $\left(\mathrm{mm}^{-3}\right)$

Trabecular thickness $(\mu \mathrm{m})$

Trabecular number $(1 / \mathrm{mm})$

Trabecular spacing $(\mu \mathrm{m})$

Distal Femur Epiphysis (cancellous bone)

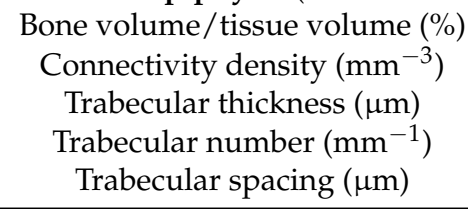

\author{
$2.32 \pm 0.03$ \\ $0.462 \pm 0.009$ \\ $0.199 \pm 0.002$
}

0.592

0.762

0.918

$$
\begin{gathered}
3.27 \pm 0.07 \\
2.18 \pm 0.04 \\
1.09 \pm 0.04 \\
765 \pm 9 \\
16.67 \pm 0.67
\end{gathered}
$$

$$
\begin{gathered}
3.25 \pm 0.06 \\
2.12 \pm 0.03 \\
1.13 \pm 0.04 \\
741 \pm 9 \\
16.18 \pm 0.54
\end{gathered}
$$

$$
\begin{gathered}
20.0 \pm 1.3 \\
63.6 \pm 4.4 \\
70 \pm 2 \\
3.9 \pm 0.1 \\
253 \pm 7
\end{gathered}
$$

$$
\begin{gathered}
23.1 \pm 1.2 \\
67.1 \pm 4.6 \\
75 \pm 2 \\
4.0 \pm 0.1 \\
243 \pm 7 \\
\\
\\
38.0 \pm 0.7 \\
33.6 \pm 1.0 \\
102 \pm 1 \\
3.7 \pm 0.1 \\
260 \pm 5
\end{gathered}
$$

Data are mean $\pm \mathrm{SE} ; n=14-16 /$ group.

\section{Discussion}

The effects of 18 weeks of hypothalamic rAAV-Lep gene therapy and involuntary caloric restriction to equalize body weight on food intake, abdominal adipose tissue, serum leptin and adiponectin, bone marrow adipose tissue, and bone were evaluated in 9-month-old female Sprague-Dawley rats. rAAV-Lep treated rats maintained body weight at pretreatment levels and calorically-restricted rats did not differ in weight from rAAV-Lep treated rats, indicating success of weight matching. Compared to rAAV-Lep treated rats, weight matched rats consumed $15 \%$ less food, had lower BAT Ucp-1 mRNA expression and, by experimental design, lower hypothalamic Lep mRNA expression. Calorically-restricted weight matched rats also differed from rAAV-Lep treated animals in having higher WAT mass, higher bone marrow adiposity, and higher serum leptin and adiponectin levels. Femur bone mineral density, bone microarchitecture, and global markers of bone turnover in serum did not differ between rAAV-Lep and calorically-restricted rats.

The effects of obesogenic diets (diets where fat typically contributes $45-60 \%$ of energy; this contrasts with normal rodent chow, which contains $\sim 10 \%$ of energy from fat) on weight gain and health outcomes have been extensively studied in rodents. These diets are typically used to induce rapid weight gain. However, in wealthy countries, energy intake in excess of the range required to achieve energy balance, rather than a preponderance of dietary fat, is the major driver of weight gain in most adults. Bone elongation ceases in female Sprague-Dawley rats at $\sim 8$ months of age [25], indicating cessation of linear 
growth. However, as in humans, body weight continues to increase during adulthood, even when rats are fed a normal diet [26]. In a prior study, female Sprague-Dawley rats fed a normal diet increased in weight by $16 \%$ between 8 and 12 months of age [27]. It is well established that weight loss induced by severe voluntary caloric restriction results in adaptive metabolic responses that act to diminish the magnitude of the resulting negative energy balance. These adaptive responses are believed to contribute to post-diet intervention weight regain [28]. However, it is less clear whether milder caloric restriction, used to promote weight stabilization in adults by achieving a neutral energy balance, results in similar adaptive responses.

In the current study, mild caloric restriction and hypothalamic rAAV-Lep treatment were similarly effective in preventing weight gain, but there were metabolic differences in how the treatments led to weight stabilization. Increasing leptin levels in leptin-deficient humans and mice decreases weight, primarily, by reducing appetite, but there is evidence, at least in rodents, that leptin also increases energy expenditure [29]. In this regard, hypothalamic leptin gene therapy in rats able to generate leptin in WAT was shown to stabilize body weight without decreasing appetite [24]. Thus, rAAV-Lep treatment prevents weight gain, at least in part, by mechanisms not requiring a decrease in appetite. Weight maintenance using caloric restriction results in lower energy intake compared to hypothalamic rAAV-Lep gene therapy, which is a limitation for effective long duration weight control, at least in animal models, because food consumption increases following a return to ad lib feeding [30].

The higher Ucp-1 gene expression levels in BAT suggest that rAAV-Lep treatment increases energy expenditure, at least in part, by increasing non-shivering thermogenesis, a finding in agreement with numerous studies [22,31,32]. Interestingly, rAAV-Lep treatment not only decreased abdominal WAT mass compared to mild caloric restriction, but it may have decreased steady state mRNA levels for leptin in WAT. Thus, in addition to decreasing fat mass, increasing leptin in the hypothalamus may reduce serum leptin by decreasing leptin production by adipocytes. However, this possibility requires verification.

The peptide hormones adiponectin and leptin are primarily, if not exclusively, synthesized by adipocytes, but their pattern of secretion often differs. Excess weight gain is associated with elevated circulating leptin and decreased circulating adiponectin [33]. Physiologically, this may be important because adiponectin, as well as leptin, can act to increase insulin sensitivity and/or function as immune system modulators [34]. We were, therefore, initially surprised to find that rAAV-Lep treatment, while decreasing abdominal WAT mass and serum leptin compared to caloric restriction, also resulted in lower levels of serum adiponectin. Individuals with anorexia have elevated serum adiponectin in spite of very low WAT. It has been suggested that adiponectin produced by bMAT, which typically increases during severe caloric restriction, contributes to high adiponectin levels [35]. If this interpretation is correct, the higher bMAT may be responsible, at least in part, for the higher serum adiponectin observed, in the current study, in calorically-restricted rats.

Decreased energy expenditure following weight loss, even after accounting for the change in body mass, is observed in humans and may contribute to the poor success of dieting as a strategy for long-duration weight maintenance [36]. As shown here, and in previous studies, increasing hypothalamic leptin levels prevents weight gain by mechanisms that do not require reduced appetite. In contrast, prevention of weight gain, in the weight matched rats, required $15 \%$ reduction in food, totaling $286 \mathrm{~g}$ over the 18 -week study. This large difference in energy intake necessary for weight stability, combined with the observed lower WAT mass and higher Ucp 1 mRNA levels in BAT, strongly suggest that rAAV-Lep prevents weight gain, in part, by increasing energy expenditure. These findings provide support for the possibility that increasing hypothalamic leptin levels in human subjects, following massive weight loss, can act to facilitate weight maintenance [37-39].

Leptin signaling is required for normal skeletal maturation; leptin deficiency in growing mice results in reduced longitudinal bone growth, osteopenia, and osteopetrosis [40-45]. Skeletal abnormalities are also observed in leptin receptor-deficient $d b / d b$ mice and $f a / f a$ 
rats $[46,47]$, and these abnormalities are likely responsible for the decreased bone strength observed in leptin-deficient and leptin receptor-deficient rodents $[48,49]$. Severe caloric restriction, resulting in rapid weight loss, results in bone loss in rats [14]. However, dietmediated modulation of serum leptin levels associated with moderate weight gain had no effect on bone mass, microarchitecture, or turnover in skeletally mature rats [26]. Similarly, in the present study, increasing hypothalamic leptin levels via rAAV-Lep gene therapy prevented the anticipated age-related weight gain but had no effect on femur mass, density, or microarchitecture compared to caloric restriction. The present study, performed in normal rats, and prior studies, performed in $o b / o b$ mice, suggest that, although extremely important, the actions of leptin to facilitate normal bone growth and turnover occur at low circulating levels of the hormone, which were achieved in the present study $[19,50]$.

This study was performed in ovary-intact female rats. This is a limitation because gonadal hormone insufficiency, induced by ovariectomy in rats or following menopause in women, accelerates normal age-related total weight gain and/or adipose tissue gain [51,52]. Additionally, age-associated weight gain is common in males of both species. These limitations are somewhat addressed by studies demonstrating the effectiveness rAAVLep in reducing weight gain in adult male and adult ovariectomized rodents fed normal or high fat diets $[22,53,54]$. An additional limitation is delivering a viral vector into the hypothalamus to control normal weight gain. Therefore, this study should be viewed as a proof of principle. Future research is encouraged to identify less invasive alternative approaches to increase the transport of leptin across the blood brain barrier to further test the hypothesis that increasing the concentration of leptin in the hypothalamus can overcome leptin resistance.

In summary, caloric restriction and increasing hypothalamic leptin, via rAAV-Lep gene therapy, were equally effective in weight maintenance but elicited different metabolic adaptations. The former led to greater adipose tissue storage in abdominal WAT and bone marrow, and the latter stabilized weight without reducing appetite. Future research should focus on elucidating the precise mechanism responsible for these effects. Reduction in metabolic rate, associated with diet-induced weight loss, is considered to be a major cause for post-diet weight regain. Our findings suggest that elevating hypothalamic leptin levels would be a more effective strategy than dieting for long term weight maintenance.

\section{Materials and Methods}

\subsection{Experimental Design}

Nine-month-old female Sprague-Dawley rats were obtained from Harlan (Indianapolis, IN, USA) and maintained under specific pathogen-free conditions in accordance with the NIH Guide for the Care and Use of Laboratory Animals. Nine-month-old rats were used because linear growth has ceased [25], but the animals continue to increase slowly in weight [55], mimicking age-related weight gain in humans. The rats were housed individually in a temperature $\left(21-23^{\circ} \mathrm{C}\right)$ and light-controlled room; lights were on from 6 a.m. to 6 p.m. The experimental protocol was approved (IACUC \#D642; 1-13-2004) by the Institutional Animal Care and Use Committee at the University of Florida.

The rats were randomized, by weight, into one of two treatment groups: rAAV-Lep $(n=16)$ and weight-matched $(n=15)$. The rAAV-Lep rats were implanted with a cannula in the 3rd ventricle of the hypothalamus and injected with rAAV-Lep as detailed below. The weight-matched group was calorically-restricted to match the weight of the rAAV-Lep group. The rats were weighed and food consumption (standard rat chow) was determined weekly for the 18-week duration of study. 18 weeks represents $~ 15 \%$ of the expected adult lifespan in this animal model.

\section{2. rAAV Vector Administration}

The rAAV-Lep vector was constructed, packaged, and administered as described [22,31,32,56-58]. To summarize, the vector pTR-CBA-Ob EcoRI fragment of pCRrOb containing rat leptin cDNA was subcloned into $\mathrm{rAAV}$ vector plasmid $\mathrm{pAAV} \beta \mathrm{GEnh}$ 
after deleting the EcoRI fragment carrying the $\beta$-glucoronidase cDNA sequence. The rats were anesthetized and stereotaxically implanted with a permanent cannula in the 3rd cerebroventricle of the hypothalamus. The coordinates employed for microinjector placement were determined using the rat brain atlas. After 1 week of recovery, rats were injected intracerebroventricularly with $7.7 \times 10^{11}$ virus particles in $5 \mu \mathrm{L}$. Localization and biological response to $\mathrm{AAV}$-Lep vector administration into the 3rd cerebroventricle of the hypothalamus of rats are documented [20,31,32].

\subsection{Tissue Collection at Necropsy}

Overnight fasted (12-16 h) rats were anesthetized with $2-3 \%$ isoflurane and blood collected from the abdominal aorta. The animals were then euthanized by decapitation. Serum was frozen at $-20{ }^{\circ} \mathrm{C}$ for analysis of leptin, adiponectin, glucose, CTX, and osteocalcin. Brains were removed and hypothalamus excised and stored in RNAlater (Ambion, Austin, TX, USA) for analysis of Lep gene expression. Abdominal WAT (mesenteric and retroperitoneal) was excised and weighed. Samples of WAT were stored in RNAlater for analyses of Lep and Adipoq gene expression. Interscapular BAT was removed and stored in RNAlater for analysis of $U_{c p}-1$ gene expression. Femora and tibiae were collected and stored in $70 \%$ ethanol for analysis of bone mass, density, microarchitecture (femur) and bone marrow adiposity (tibia).

\subsection{RNA Analysis}

Total cellular RNA was isolated from the entire hypothalamus, abdominal WAT, and interscapular BAT, as described [24]. cDNA for RT-PCR was synthesized using SuperScript First-Strand Synthesis System for RT-PCR (Invitrogen, Carlsbad, CA, USA) and analyzed using primers for rat $18 \mathrm{~S}$ ribosomal (18S), leptin and Ucp-1 RNA as described [24]. A standard curve, generated from serial dilutions of purified plasmid DNA that encoded the respective genes, was used to measure mRNA transcript copy number. mRNA data represent normalized copy number using the $18 S$ ribosomal RNA gene. Predesigned KiCqStart SYBR Green rat adiponectin primers were purchased from Sigma (St Louis, MO, USA).

\subsection{Serum Assays}

Serum leptin, adiponectin, glucose, CTX, and osteocalcin were measured as described $[24,59]$.

\subsection{Histomorphometry}

For evaluation of bone marrow adiposity in proximal tibia, longitudinal sections (5 $\mu \mathrm{m}$ thick) were cut on a Jung Reichart microtome as described [60]. Measurements were performed in unstained sections under ultraviolet illumination in a sampling site located in the metaphysis, immediately below the growth plate. All measurements were performed with the OsteoMeasure Image Analysis system (OsteoMetrics, Inc., Decatur, GA, USA). Bone marrow adiposity (adipocyte area/tissue area, \%), adipocyte number (number/tissue area, $\left.\# / \mathrm{mm}^{2}\right)$, and adipocyte size $\left(\mu \mathrm{m}^{2}\right)$ were determined as described [61].

\subsection{Densitometry}

Total femur bone mineral content (BMC, g), bone area $\left(\mathrm{cm}^{2}\right)$, and bone mineral density (BMD, $\mathrm{g} / \mathrm{cm}^{2}$ ) were measured using DXA (Piximus 2, Lunar Corporation, Madison, WI, USA).

\subsection{Microcomputed Tomography}

$\mu \mathrm{CT}$ was used for nondestructive three-dimensional evaluation of bone architecture. Femurs were scanned using a Scanco $\mu \mathrm{CT} 40$ scanner (Scanco Medical AG, Basserdorf, Switzerland) at a voxel size of $16 \times 16 \times 16 \mu \mathrm{m}$ and evaluated at a threshold of 245 (gray scale, 0-1000). Cortical bone was evaluated at the midshaft, and cancellous bone 
was evaluated in the distal femoral metaphysis and epiphysis. For the femoral midshaft, 20 slices $(0.32 \mathrm{~mm})$ of bone were evaluated, and (1) total cross-sectional tissue volume (cortical and marrow volume, $\left.\mathrm{mm}^{3}\right),(2)$ cortical volume $\left(\mathrm{mm}^{3}\right),(3)$ marrow volume $\left(\mathrm{mm}^{3}\right)$, and (4) cortical thickness $(\mu \mathrm{m})$ were measured. Polar moment of inertia $\left(\mathrm{mm}^{4}\right)$ was determined as a surrogate measure of bone strength in torsion. For the distal femoral metaphysis, 75 slices $(1.2 \mathrm{~mm})$ of bone 150 slices $(2.4 \mathrm{~mm})$ proximal to the growth plate were measured and included secondary spongiosa only. For the distal femur epiphysis $60 \pm 1$ slices $(0.96 \pm 0.01 \mathrm{~mm}$; entire cancellous compartment) were evaluated. Direct cancellous bone measurements included: (1) cancellous bone volume/tissue volume (\%), (2) connectivity density $\left(\mathrm{mm}^{-3}\right)$, (3) trabecular thickness $(\mu \mathrm{m}),(4)$ trabecular number $\left(\mathrm{mm}^{-1}\right)$, and $(4)$ trabecular separation $(\mu \mathrm{m})$.

\subsection{Statistical Analysis}

Data from adult female rats, randomized to either the rAAV-Lep group or a weightmatched calorically-restricted control group, were analyzed to compare mean outcomes using t-tests (with or without equal variance) or the Wilcoxon-Mann-Whitney test. The decision to use a parametric or nonparametric test was based on quantile-quantile plots and the Anderson-Darling test to assess normality. Residual analysis and Levene's test were used to assess homogeneity of variance. The time course data in Figure 1 was analyzed using repeated measures ANOVA. The Benjamini and Hochberg method, for maintaining the false discovery rate at $5 \%$, was used to adjust for multiple comparisons [62]. Differences were considered significant at $p \leq 0.05$. All data are presented as mean $\pm \mathrm{SE}$. Data analysis was performed using $\mathrm{R}$ version 3.6 .3

Author Contributions: Conceptualization, R.T.T. and U.T.I.; Methodology, C.P.W., R.T.T., K.M.F.; Formal analysis, A.J.B.; Writing-Original draft preparation, R.T.T.; Writing-Review and editing, R.T.T., A.J.B., C.P.W., K.M.F., U.T.I.; Funding acquisition: U.T.I., R.T.T., A.J.B., C.P.W. All authors have read and agreed to the published version of the manuscript.

Funding: This research was supported by National Institutes of Health (AR060913) and the Department of Defense (W81XWH-04-1-0701).

Institutional Review Board Statement: The experimental protocol was approved (IACUC \#D642; 1-13-2004) by the Institutional Animal Care and Use Committee at the University of Florida.

Data Availability Statement: All relevant data are included within the manuscript. Raw data will be made available from the corresponding author upon reasonable request.

Conflicts of Interest: The authors declare no conflict of interest.

$\begin{array}{ll}\text { Abbreviations } \\ \text { BAT } & \text { Brown adipose tissue } \\ \text { bMAT } & \text { Bone marrow adipose tissue } \\ \text { DXA } & \text { Dual energy x-ray absorptiometry } \\ \text { GFP } & \text { Green fluorescent protein } \\ \mu C T & \text { Microcomputed tomography } \\ \text { rAAV } & \text { Recombinant adeno-associated virus } \\ \text { Ucp-1 } & \text { Uncoupling protein 1 } \\ \text { W-M } & \text { Weight-matched } \\ \text { WAT } & \text { White adipose tissue }\end{array}$

\section{References}

1. Hutfless, S.; Maruthur, N.M.; Wilson, R.F.; Gudzune, K.A.; Brown, R.; Lau, B.; Fawole, O.A.; Chaudhry, Z.W.; Anderson, C.A.M.; Segal, J.B. Strategies to prevent weight gain among adults. In Strategies to Prevent Weight Gain Among Adults; AHRQ Comparative Effectiveness Reviews, No. 97; NCBI Bookshelf: Rockville, MD, USA, 2013.

2. Malhotra, R.; Østbye, T.; Riley, C.M.; Finkelstein, E.A. Young adult weight trajectories through midlife by body mass category. Obesity 2013, 21, 1923-1934. [CrossRef] [PubMed] 
3. Changzheng, Y.; Manson, J.E.; Yuan, C.; Liang, M.H.; Grodstein, F.; Stampfer, M.J.; Willett, W.C.; Hu, F.B. Associations of Weight Gain from Early to Middle Adulthood with Major Health Outcomes Later in Life. JAMA 2017, 318, 255-272. [CrossRef]

4. Gruzdeva, O.; Borodkina, D.; Uchasova, E.; Dyleva, Y.; Barbarash, O. Leptin resistance: Underlying mechanisms and diagnosis. Diabetes Metab. Syndr. Obes. 2019, 12, 191-198. [CrossRef] [PubMed]

5. Zhao, S.; Kusminski, C.M.; Elmquist, J.K.; Scherer, P.E. Leptin: Less Is More. Diabetes 2020, 69, 823-829. [CrossRef] [PubMed]

6. Breitkopf, C.R.; Berenson, A.B. Correlates of Weight Loss Behaviors among Low-Income African-American, Caucasian, and Latina Women. Obstet. Gynecol. 2004, 103, 231-239. [CrossRef]

7. Montani, J.-P.; Schutz, Y.; Dulloo, A. Dieting and weight cycling as risk factors for cardiometabolic diseases: Who is really at risk? Obes. Rev. 2015, 16, 7-18. [CrossRef]

8. Santos, I.; Sniehotta, F.; Marques, M.M.; Carraça, E.; Teixeira, P.J. Prevalence of personal weight control attempts in adults: A systematic review and meta-analysis. Obes. Rev. 2017, 18, 32-50. [CrossRef] [PubMed]

9. Slof-Op 't Landt, M.C.T.; van Furth, E.F.; van Beijsterveldt, C.E.M.; Bartels, M.; Willemsen, G.; de Geus, E.J.; Ligthart, L.; Boomsma, D.I. Prevalence of dieting and fear of weight gain across ages: A community sample from adolescents to the elderly. Int. J. Public Health 2017, 62, 911-919. [CrossRef] [PubMed]

10. Elfhag, K.; Rossner, S. Who succeeds in maintaining weight loss? A conceptual review of factors associated with weight loss maintenance and weight regain. Obes. Rev. 2005, 6, 67-85. [CrossRef]

11. Wu, T.; Gao, X.; Chen, M.; Van Dam, R.M. Long-term effectiveness of diet-plus-exercise interventions vs. diet-only interventions for weight loss: A meta-analysis. Obes. Rev. 2009, 10, 313-323. [CrossRef]

12. Yaskin, J.; Toner, R.W.; Goldfarb, N. Obesity Management Interventions: A Review of the Evidence. Popul. Health Manag. 2009, 12, 305-316. [CrossRef]

13. Hohman, E.E.; Balantekin, K.N.; Birch, L.L.; Savage, J.S. Dieting is associated with reduced bone mineral accrual in a longitudinal cohort of girls. BMC Public Health 2018, 18, 1285. [CrossRef]

14. Turner, R.T.; Iwaniec, U.T. Low dose parathyroid hormone maintains normal bone formation in adult male rats during rapid weight loss. Bone 2011, 48, 726-732. [CrossRef] [PubMed]

15. Chen, C.; Ye, Y.; Zhang, Y.; Pan, X.-F.; Pan, A. Weight change across adulthood in relation to all cause and cause specific mortality: Prospective cohort study. BMJ 2019, 367, 15584. [CrossRef]

16. Chen, Y.; Yang, X.; Wang, J.; Li, Y.; Ying, D.; Yuan, H. Weight loss increases all-cause mortality in overweight or obese patients with diabetes: A meta-analysis. Medicine 2018, 97, e12075. [CrossRef]

17. Gregg, E.W.; Gerzoff, R.B.; Thompson, T.J.; Williamson, D.F. Intentional Weight Loss and Death in Overweight and Obese U.S. Adults 35 Years of Age and Older. Ann. Intern. Med. 2003, 138, 383-389. [CrossRef]

18. Affinati, A.H.; Myers, M.G., Jr. Neuroendocrine control of body energy homeostasis. In Endotext; Feingold, K.R., Anawalt, B., Boyce, A., Chrousos, G., de Herder, W.W., Dhatariya, K., Dungan, K., Grossman, A., Eds.; MDText.com, Inc.: Dartmouth, MA, USA, 2000.

19. Philbrick, K.A.; Wong, C.P.; Branscum, A.J.; Turner, R.T.; Iwaniec, U.T. Leptin stimulates bone formation in $o b / o b$ mice at doses having minimal impact on energy metabolism. J. Endocrinol. 2017, 232, 461-474. [CrossRef] [PubMed]

20. Boghossian, S.; Lecklin, A.; Torto, R.; Kalra, P.S.; Kalra, S.P. Suppression of fat deposition for the life time with gene therapy. Peptides 2005, 26, 1512-1519. [CrossRef] [PubMed]

21. Dhillon, H.; Kalra, S.P.; Prima, V.; Zolotukhin, S.; Scarpace, P.J.; Moldawer, L.L.; Muzyczka, N.; Kalra, P.S. Central leptin gene therapy suppresses body weight gain, adiposity and serum insulin without affecting food consumption in normal rats: A long-term study. Regul. Pept. 2001, 99, 69-77. [CrossRef]

22. Dube, M.G.; Beretta, E.; Dhillon, H.; Ueno, N.; Kalra, P.S.; Kalra, S.P. Central leptin gene therapy blocks high-fat diet-induced weight gain, hyperleptinemia, and hyperinsulinemia: Increase in serum ghrelin levels. Diabetes 2002, 51, 1729-1736. [CrossRef]

23. Van Heek, M.; Compton, D.S.; France, C.F.; Tedesco, R.P.; Fawzi, A.B.; Graziano, M.P.; Sybertz, E.J.; Strader, C.D.; Davis, H.R. Diet-induced obese mice develop peripheral, but not central, resistance to leptin. J. Clin. Investig. 1997, 99, 385-390. [CrossRef] [PubMed]

24. Turner, R.T.; Dube, M.; Branscum, A.J.; Wong, C.P.; Olson, D.A.; Zhong, X.; Kweh, M.F.; Larkin, I.V.; Wronski, T.J.; Rosen, C.J.; et al. Hypothalamic leptin gene therapy reduces body weight without accelerating age-related bone loss. J. Endocrinol. 2015, 227, 129-141. [CrossRef]

25. Martin, E.A.; Ritman, E.L.; Turner, R.T. Time course of epiphyseal growth plate fusion in rat tibiae. Bone 2003, 32, $261-267$. [CrossRef]

26. Turner, R.; Iwaniec, U.; Turner, R.; Iwaniec, U. Moderate weight gain does not influence bone metabolism in skeletally mature female rats. Bone 2010, 47, 631-635. [CrossRef]

27. Turner, R.T.; Kidder, L.S.; Kennedy, A.; Evans, G.L.; Sibonga, J.D. Moderate Alcohol Consumption Suppresses Bone Turnover in Adult Female Rats. J. Bone Miner. Res. 2001, 16, 589-594. [CrossRef] [PubMed]

28. Busetto, L.; Bettini, S.; Makaronidis, J.; Roberts, C.A.; Halford, J.C.G.; Batterham, R.L. Mechanisms of weight regain. Eur. J. Intern. Med. 2021, in press. [CrossRef] [PubMed]

29. Jéquier, E. Leptin Signaling, Adiposity, and Energy Balance. Ann. N. Y. Acad. Sci. 2006, 967, 379-388. [CrossRef] [PubMed]

30. Levin, B.E.; Keesey, R.E. Defense of differing body weight set points in diet-induced obese and resistant rats. Am. J. Physiol. 1998, 274, R412-R419. 
31. Dhillon, H.; Kalra, S.P.; Kalra, P.S. Dose-Dependent Effects of Central Leptin Gene Therapy on Genes That Regulate Body Weight and Appetite in the Hypothalamus. Mol. Ther. 2001, 4, 139-145. [CrossRef] [PubMed]

32. Beretta, E.; Dube, M.G.; Kalra, P.S.; Kalra, S.P. Long-term suppression of weight gain, adiposity, and serum insulin by central leptin gene therapy in prepubertal rats: Effects on serum ghrelin and appetite-regulating genes. Pediatric Res. 2002, 52, 189-198. [CrossRef]

33. Tsao, T.-S.; Lodish, H.F.; Fruebis, J. ACRP30, a new hormone controlling fat and glucose metabolism. Eur. J. Pharmacol. 2002, 440, 213-221. [CrossRef]

34. Burhans, M.S.; Hagman, D.K.; Kuzma, J.N.; Schmidt, K.A.; Kratz, M. Contribution of Adipose Tissue Inflammation to the Development of Type 2 Diabetes Mellitus. Compr. Physiol. 2018, 9, 1-58. [CrossRef] [PubMed]

35. Cawthorn, W.P.; Scheller, E.L.; Learman, B.S.; Parlee, S.D.; Simon, B.R.; Mori, H.; Ning, X.; Bree, A.J.; Schell, B.; Broome, D.T.; et al. Bone Marrow Adipose Tissue Is an Endocrine Organ that Contributes to Increased Circulating Adiponectin during Caloric Restriction. Cell Metab. 2014, 20,368-375. [CrossRef]

36. Rosenbaum, M.; Leibel, R.L. Adaptive thermogenesis in humans. Int. J. Obes. 2010, 34, S47-S55. [CrossRef]

37. Friedman, J.M. Leptin and the endocrine control of energy balance. Nat. Metab. 2019, 1, 754-764. [CrossRef]

38. Kelesidis, T.; Kelesidis, I.; Chou, S.; Mantzoros, C.S. Narrative review: The role of leptin in human physiology: Emerging clinical applications. Ann. Intern. Med. 2010, 152, 93-100. [CrossRef]

39. Rosenbaum, M.; Sy, M.; Pavlovich, K.; Leibel, R.L.; Hirsch, J. Leptin reverses weight loss-induced changes in regional neural activity responses to visual food stimuli. J. Clin. Investig. 2008, 118, 2583-2591. [CrossRef] [PubMed]

40. Ealey, K.N.; Fonseca, D.; Archer, M.C.; Ward, W.E. Bone abnormalities in adolescent leptin-deficient mice. Regul. Pept. 2006, 136, 9-13. [CrossRef] [PubMed]

41. Garris, D.R.; Burkemper, K.M.; Garris, B.L. Influences of diabetes $(d b / d b)$, obese $(o b / o b)$ and dystrophic $(d y / d y)$ genotype mutations on hind limb bone maturation: A morphometric, radiological and cytochemical indices analysis. Diabetes Obes. Metab. 2007, 9, 311-322. [CrossRef]

42. Hamrick, M.W.; Della-Fera, M.A.; Choi, Y.-H.; Pennington, C.; Hartzell, D.; Baile, C.A. Leptin Treatment Induces Loss of Bone Marrow Adipocytes and Increases Bone Formation in Leptin-Deficient ob/ob Mice. J. Bone Miner. Res. 2005, 20, $994-1001$. [CrossRef]

43. Hamrick, M.; Pennington, C.; Newton, D.; Xie, D.; Isales, C. Leptin deficiency produces contrasting phenotypes in bones of the limb and spine. Bone 2004, 34, 376-383. [CrossRef]

44. Steppan, C.M.; Crawford, D.; Chidsey-Frink, K.L.; Ke, H.; Swick, A.G. Leptin is a potent stimulator of bone growth in $o b / o b$ mice. Regul. Pept. 2000, 92, 73-78. [CrossRef]

45. Yagasaki, Y.; Yamaguchi, T.; Watahiki, J.; Konishi, M.; Katoh, H.; Maki, K. The role of craniofacial growth in leptin deficient ( $o b / o b)$ mice. Orthod. Craniofacial Res. 2003, 6, 233-241. [CrossRef]

46. Atar, M.; Yasmin, R.; Sharma, R.; Le Comber, S.C.; Verry, P.; Polly, P.D. Of mice and mutations: Phenotypic effects of the diabetic $d b / d b$ and $o b / o b$ mutations on the skull and teeth of mice. Eur. Arch. Paediatr. Dent. 2008, 9, 37-40. [CrossRef]

47. Tamasi, J.A.; Arey, B.J.; Bertolini, D.R.; Feyen, J.H. Characterization of Bone Structure in Leptin Receptor-Deficient Zucker (fa/fa) Rats. J. Bone Miner. Res. 2003, 18, 1605-1611. [CrossRef]

48. Hamann, C.; Picke, A.-K.; Campbell, G.M.; Balyura, M.; Rauner, M.; Bernhardt, R.; Huber, G.; Morlock, M.; Günther, K.-P.; Bornstein, S.R.; et al. Effects of Parathyroid Hormone on Bone Mass, Bone Strength, and Bone Regeneration in Male Rats with Type 2 Diabetes Mellitus. Endocrinology 2014, 155, 1197-1206. [CrossRef]

49. Williams, G.A.; Callon, K.E.; Watson, M.; Costa, J.L.; Ding, Y.; Dickinson, M.; Wang, Y.; Naot, D.; Reid, I.R.; Cornish, J. Skeletal phenotype of the leptin receptor-deficient $d b / d b$ mouse. J. Bone Miner. Res. 2011, 26, 1698-1709. [CrossRef]

50. Iwaniec, U.T.; Boghossian, S.; Lapke, P.D.; Turner, R.T.; Kalra, S.P. Central leptin gene therapy corrects skeletal abnormalities in leptin-deficient $o b / o b$ mice. Peptides 2007, 28, 1012-1019. [CrossRef]

51. Evans, G.L.; Bryant, H.U.; Magee, D.E.; Turner, R.T. Raloxifene inhibits bone turnover and prevents further cancellous bone loss in adult ovariectomized rats with established osteopenia. Endocrinology 1996, 137, 4139-4144. [CrossRef] [PubMed]

52. Kapoor, E.; Collazo-Clavell, M.L.; Faubion, S.S. Weight Gain in Women at Midlife: A Concise Review of the Pathophysiology and Strategies for Management. Mayo Clin. Proc. 2017, 92, 1552-1558. [CrossRef]

53. Lindenmaier, L.B.; Philbrick, K.A.; Branscum, A.J.; Kalra, S.P.; Turner, R.T.; Iwaniec, U.T. Hypothalamic Leptin Gene Therapy Reduces Bone Marrow Adiposity in ob/ob Mice Fed Regular and High-Fat Diets. Front. Endocrinol. 2016, 7, 110. [CrossRef]

54. Torto, R.; Boghossian, S.; Dube, M.G.; Kalra, P.S.; Kalra, S.P. Central Leptin Gene Therapy Blocks Ovariectomy-Induced Adiposity. Obesity 2006, 14, 1312-1319. [CrossRef] [PubMed]

55. Iwaniec, U.T.; Boghossian, S.; Trevisiol, C.H.; Wronski, T.J.; Turner, R.T.; Kalra, S.P. Hypothalamic leptin gene therapy prevents weight gain without long-term detrimental effects on bone in growing and skeletally mature female rats. J. Bone Miner. Res. 2011, 26, 1506-1516. [CrossRef] [PubMed]

56. Dhillon, H. Effects of Recombinant Adeno-Associated Virus Encoding Leptin on Body Weight Regulation and Energy Homeostasis. Ph.D. Thesis, University of Florida, Gainesville, FL, USA, 2000. Available online: http:/ / purl.fcla.edu/fcla/etd/ane5948 (accessed on 20 June 2021). 
57. Dhillon, H.; Ge, Y.-L.; Minter, R.; Prima, V.; Moldawer, L.; Muzyczka, N.; Zolotukhin, S.; Kalra, P.; Kalra, S. Long-term differential modulation of genes encoding orexigenic and anorexigenic peptides by leptin delivered by rAAV vector in $o b / o b$ mice. Regul. Pept. 2000, 92, 97-105. [CrossRef]

58. Zolotukhin, S.; Byrne, B.J.; Mason, E.; Zolotukhin, I.; Potter, M.; Chesnut, K.; Summerford, C.; Samulski, R.J.; Muzyczka, N Recombinant adeno-associated virus purification using novel methods improves infectious titer and yield. Gene Ther. 1999, 6, 973-985. [CrossRef]

59. Turner, R.T.; Philbrick, K.A.; Wong, C.P.; Olson, D.A.; Branscum, A.J.; Iwaniec, U.T. Morbid obesity attenuates the skeletal abnormalities associated with leptin deficiency in mice. J. Endocrinol. 2014, 223, M1-M15. [CrossRef]

60. Iwaniec, U.T.; Wronski, T.J.; Turner, R.T. Histological Analysis of Bone. Methods Mol. Biol. 2008, 447, 325-341. [CrossRef]

61. Maddalozzo, G.F.; Turner, R.T.; Edwards, C.H.T.; Howe, K.S.; Widrick, J.J.; Rosen, C.J.; Iwaniec, U.T. Alcohol alters whole body composition, inhibits bone formation, and increases bone marrow adiposity in rats. Osteoporos. Int. 2009, 20, 1529-1538. [CrossRef]

62. Benjamini, Y.; Hochberg, Y. Controlling the false discovery rate: A practical and powerful approach to multiple testing. J. R. Stat. Soc. Ser. B 1995, 57, 289-300. [CrossRef] 